Acta vet. scand. 1988, 29, 61-66.

From the Department of Reproduction, Royal Veterinary and Agricultural University, Denmark.

\title{
Radioimmunoassay for Luteinizing Hormone in Bovine Species Based on Commercially Available Reagents
}

\author{
By $R$. Høier
}

\begin{abstract}
Høier, R.: Radioimmunoassay for luteinizing hormone in bovine species based on commercially available reagents. Acta vet. scand. 1988, 29, 61-66. - A radioimmunoassay method based on commercially distributed antibody and antigen for measurement of bovine luteinizing hormone is presented. The method is characterized by (1) intraassay coefficient of variation (C.V.) from 1.3 to $10 \%$, and (2) interassay C.V. from 4 to $18 \%$. The specificity is illustrated by the cross reactivity of bFSH which is found to be $0.4 \%$. The method provides good correlation with a previously well characterized method. Also the influence on sensitivity of length of incubation time is discussed.
\end{abstract}

\section{Introduction}

The role of luteinizing hormone (LH) in reproductive endocrine regulatory mechanisms in cattle has been subject to extensive studies (e.g. Niswender et al. 1969; Peterson et al. 1975; Schams et al. 1977; Greve et al. 1983; Bernard et al. 1983; Walters \& Schallenberger 1984; Walters et al. 1984; Callesen et al. 1986; Goff et al. 1986), thereby emphasizing the demands for precise measurement of the hormone.

As a consequence of the development of radioimmunoassay (RIA) technique in the late fifties (reviewed by Yalow \& Berson 1971) together with advanced gonadotrophin purification, LH-RIA is now the most widespread method for quantification of bovine LH (e.g. Niswender et al. 1969; Schams \& Karg 1969; Stupnicki \& Madej 1976). The method provides high sensitivity and reproducibility in combination with a high capacity and rather low costs - once the special equipment for handling of radioisotopes is available.
Meanwhile LH-RIA has to a great extent been restricted to large and well equipped laboratory units having the facilities and resources to handle both high grade purification of protein hormones and immunization for achievement of specific antisera - or having the opportunity to be supplied from such laboratories.

In this paper a RIA method based on antiserum against bLH and purified bLH both of commercial origin is presented, and it appears to be reliable and reasonably easy to perform.

\section{Materials and methods}

Chemicals

All reagents were of analytical or higher grade. ${ }^{125}$ ( NaI) was obtained from Amersham (Bedford, UK). bLH, bFSH, rabbit-antibLH-antiserum, and immobilized anti-rabbit-IgG (2. antibody) were all purchased from UCB-bioproducts (Braine-l'Alleud, Belgium). Sephadex was supplied from Pharmacia (Uppsala, Sweden) and What- 
man cellulose CF-11 from Whatman (Maidstone, UK).

\section{Buffers for LH-RIA}

$50 \mathrm{mmol} / 1$ sodiumphosphate, $10 \mathrm{mmol} / \mathrm{l}$ EDTA, $0.1 \%$ BSA, $0.01 \%$ Thiomersal R; $\mathrm{pH}=7.50$. Wash solution: $20 \mathrm{mmol} / 1$ sodiumphosphate, $140 \mathrm{mmol} / 1$ sodiumchloride, and $0.05 \%$ Tween $20, \mathrm{pH}=7.50$.

\section{Preparation of ${ }^{125} \mathrm{I}-\mathrm{LH}$}

bLH was iodinated using the chloramin $\mathrm{T}$ oxidation method (Greenwood et al. 1963) with gel filtration over Sephadex G-25 fine as purification immediately after the reaction, the gel being equilibrated with 10 mmol/1 sodiumphosphate $\mathrm{pH}=7.50$, and eluted with $10 \mathrm{mmol} / 1$ Tris/glycin, $0.1 \%$ $\mathrm{BSA}, \mathrm{pH}=8.6$. The tracer was further purified by absorption to Whatman CF 11 cellulose and elution with 1:1 diluted equine serum. Each tracer preparation is characterized by self-displacement analysis (Calvo et al. 1983) and normally a specific activity around $50 \mathrm{Ci} / \mathrm{g}$ corresponding to $0.7{ }^{125} \mathrm{I}$ atom per LH molecule is achieved. The tracer was stored at $-20^{\circ} \mathrm{C}$, cellulose purification was performed once a week. Per assay 20,000-30,000 cpm was used.

\section{Hormone solutions and controls}

The bLH is referred to have a potency equal to $0.9 \times$ Standard NIH LH-B4 and to be contaminated with bTSH $<1 \%$, bGH $<0.1 \%$, bFSH $<0.1 \%$, and it was used for iodination and for standard series ranging from 6.4 to $0.1 \mathrm{ng} /$ assay by serial dilution in buffer.

To verify cross reactivity bFSH (referred to equalize $28 \times \mathrm{NIH}$ FSH-B1 and to be contaminated with bLH $<0.6 \%$ ) was used in amounts from 125 to $7.8 \mathrm{ng}$ /assay in serial dilution.

Control plasmas were used in $3 \mathrm{LH}$ levels around $20 \%, 50 \%$, and $80 \%$ of the maximal binding.

\section{Anti-bLH-antiserum}

The antiserum is referred to have the following specificity expressed as cross reactivity: bFSH $0.5 \%$, bTSH $0.4 \%$. The antiserum was diluted with RIA-buffer to a stock solution which was frozen in aliquotes and diluted $100 \times$ before RIA. Final titer used was $120,000(100,000$ suggested by the manufacturer), in this way a maximal binding around $30 \%$, and a half maximal binding equal to 0.6-1.0 ng LH/assay was obtained when the above written amounts of tracer was added.

\section{LH-RIA procedure}

$100 \mu l$ standard, control or sample plus the above mentioned amounts of tracer and antibody are mixed in a total volume of $500 \mu 1$ and incubated at room temperature for 40 $48 \mathrm{~h}$. Separation of unbound and bound fraction by use of immobilized 2. antibody according to the manufacturer: $30 \mathrm{~min}$ incubation at room temperature, centrifugation $2500 \times \mathrm{G}$ for $15 \mathrm{~min}$ at room temperature followed by decantation. Resuspension in wash solution and repeated centrifugation and decantation. Counting of radioactivity for $2 \mathrm{~min}$ in a Selektronik solid phase scintillator.

\section{Niswender LH-RIA}

The analysis follows the protocol by Niswender et al. (1969).

\section{Blood sampling}

Sampling during induction of superovulation is described elsewhere (Callesen et al. 1986).

\section{Statistical methods}

Dose-response relation is calculated by means of a computerized log/logit transformation.

Results of measurement of $\mathrm{LH}$ using different methods were correlated by linear regression. 


\section{Results}

The LH-RIA method was characterized by the following parameters:

\section{Precision}

Precision is illustrated by intra- and interassay coefficients of variation (Table 1) and by parallelism between dose-response curve and serial dilution of plasma with a high content of LH, shown graphically in Fig. 1. Intraassay C.V. from 1.3 to $10 \%$ and interassay C.V. from 4-18\% were obtained. $\mathrm{Pa}$ rallelism is expressed by the regression lines for $\log / \operatorname{logit}$ transformation, $y=\alpha x+\beta$, (x,
Table 1. Intra- and interassay coefficients of variation (C.V.) for 5 different plasma's. Intraassay: Single determinations, $n=6-10$. Interassay: Mean of duplicates, $n=7-11$, concentrations in $\mathrm{ng} \mathrm{LH} / \mathrm{ml}$ plasma.

\begin{tabular}{lcccc}
\hline & \multicolumn{2}{c}{ Intraassay } & \multicolumn{2}{c}{ Interassay } \\
Plasma & Mean & C.V. & Mean & C.V. \\
\hline 1 & 1.06 & 0.102 & 1.24 & 0.182 \\
2 & 2.70 & 0.047 & 2.89 & 0.065 \\
3 & 3.60 & 0.031 & 3.75 & 0.048 \\
4 & 9.37 & 0.091 & 8.77 & 0.042 \\
5 & 22.2 & 0.013 & 21.1 & 0.089 \\
\hline
\end{tabular}

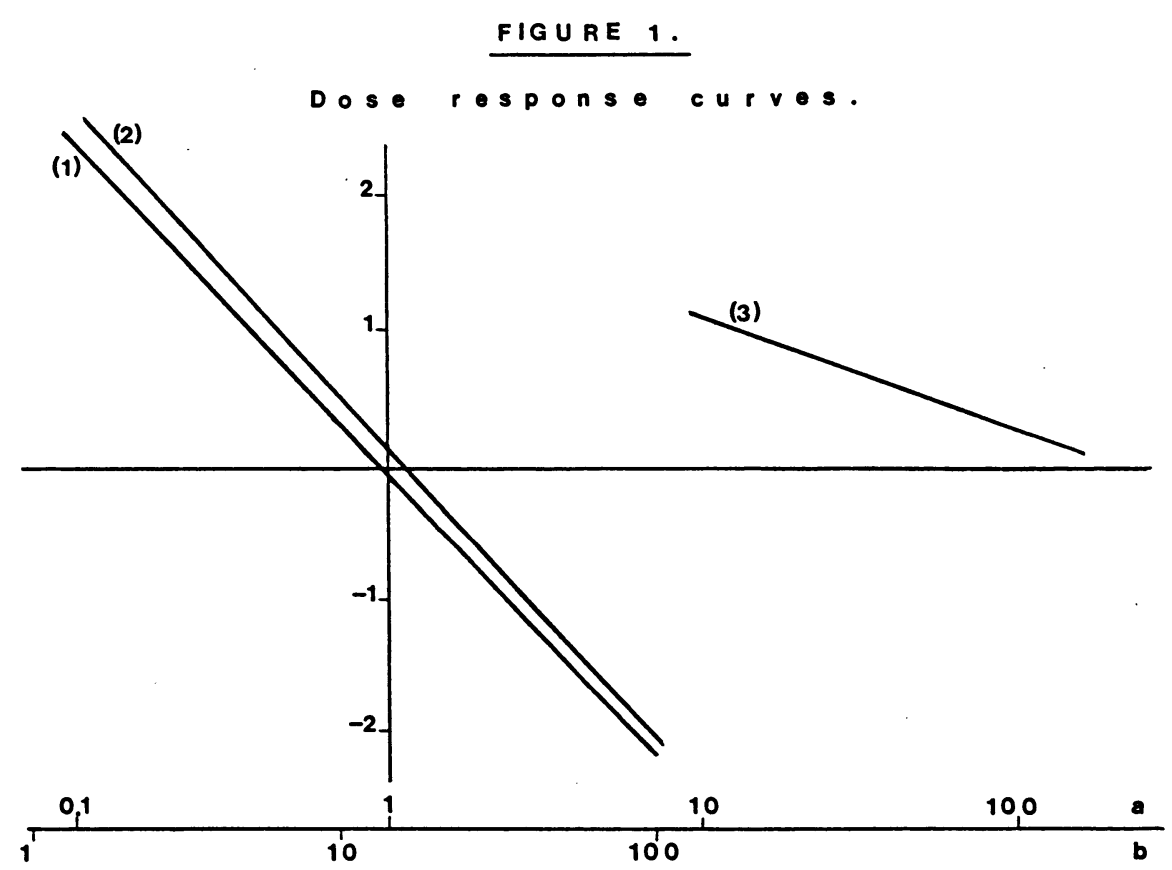

Figure 1. log/logit transformations of doseresponse relations, ordinate: (a) $=\ln$ (hormone amount per assay), (b) $=\mu$ l plasma per assay, abscissa $=$ logit to bound fraction .

(1) Standard curve for LH-RIA, regression line:

$\mathrm{y}=-1.048 \mathrm{x}-0.029 ; \mathrm{r}=-0.999$.

(2) Serial dilution of high-LH plasma, ordinate (b), regression line:

$y=-1.064 x+0.171 ; r=-0.998$.

(3) bFSH cross-reactivity in LH-RIA, regression line: 
y) $=\log _{e} c_{L H}$, logit (B): dose response curve: $y=1.048 x-0.029 ; r=-0.999$. Plasma dilution: $\mathrm{y}=1.064 \mathrm{x}+0.171 ; \mathrm{r}=-0.998$.

\section{Specificity}

Specificity is outlined by cross reactivity (C.R.) of bFSH (Figure 1) giving a C.R. of FSH, defined as the ratio between concentrations giving half maximal binding = $0.4 \%$.

\section{Sensitivity}

Sensitivity can be expressed as the amount of LH corresponding to $B_{0}$ minus twice the standard deviation on $B_{0}$; in this way the least detectable amount is below $0.05 \mathrm{ng}$ LH/assay.

The sensitivity is dependent on conditions during incubation. In Table $2 \mathrm{~A}$ the effect of change in incubation time is shown for parallel assay of plasma samples, as an over all estimation and for different levels of $\mathrm{LH}$.

For further investigation of the validity of LH-RIA samples were run in parallel by use of this method and by use of a well established method (Niswender et al. 1969). Data are presented in Table 2B and in Fig. 2.

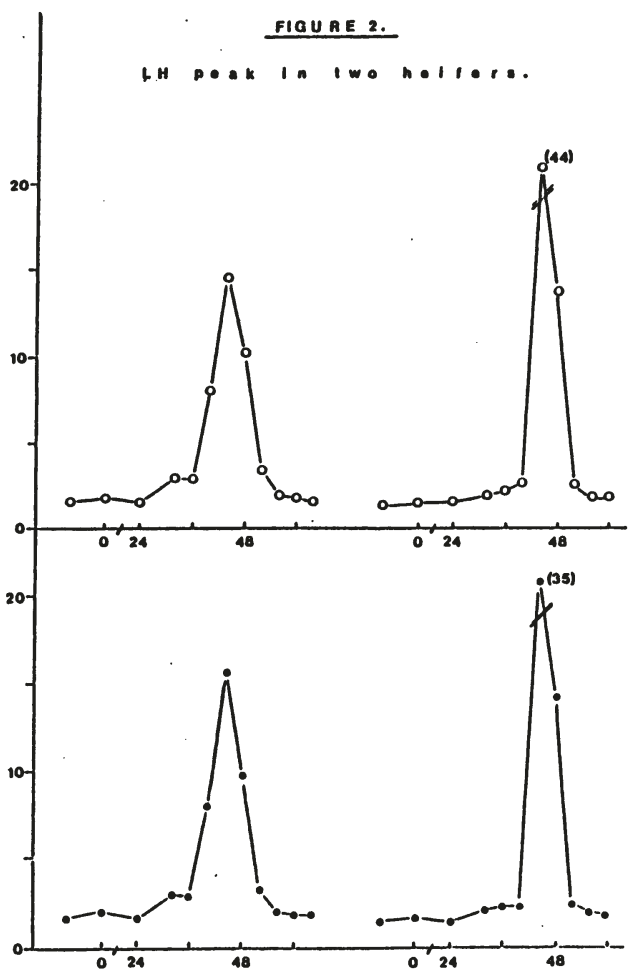

Figure 2. $\mathrm{C}_{\mathrm{LH}}$ during superovulation in two heifers, measured by LH-RIA $(0-0)$ and Niswender method $(\bullet-\bullet)$. Ordinate: time scale in hours (from PG-injection), abscissa: Concentration of $\mathrm{LH}$ in plasma (ng/ml).

Table 2. A: Comparison between values obtained after the normal incubation time (x) and $20 \mathrm{~h}$ (y). B: Comparison between the method described by Niswender et al. (1969), C-N (x) and the LH-RIA here described, C-LH (y) by use of linear regression, $y=\alpha x+\beta$. Range $=$ value of $x$ in $n g / m l, r=$ coefficient of correlation.

\begin{tabular}{rccccccc}
\hline & $\mathrm{x}$ & $\mathrm{y}$ & range & $\mathrm{n}$ & $\alpha$ & \multicolumn{1}{c}{$\beta$} & $\mathrm{r}$ \\
\hline & C-LH & C-20 & all & 28 & 1.367 & -0.446 & 0.993 \\
$\mathrm{~A}$ & - & - & $\mathrm{x}<4$ & 21 & 1.084 & 0.389 & 0.816 \\
& - & - & $\mathrm{x}>4$ & 7 & 1.510 & -3.475 & 0.995 \\
\hline & C-N & C-LH & all & 45 & 0.929 & 0.125 & 0.996 \\
$\mathrm{~B}$ & - & - & $\mathrm{x}<4$ & 21 & 1.012 & -0.150 & 0.948 \\
& - & - & $4<\mathrm{x}<15$ & 15 & 0.998 & 0.127 & 0.990 \\
& - & - & $\mathrm{x}>15$ & 9 & 0.956 & -1.230 & 0.989 \\
\hline
\end{tabular}




\section{Discussion}

The assay parameters are described as follows:

\section{Precision}

Intra- and interassay coefficients of variation are examplified in Table 1. As could be expected the variation is enhanced the longer the distance to the midpoint of the standard curve. Except for the lowest LH concentration, all C.V. values are below $10 \%$ : i.e. 4$9 \%$ between 2 and $20 \mathrm{ng} \mathrm{LH} / \mathrm{ml}$ plasma for interassay C.V. From Fig. 1 it is obvious that the slopes of the dose-response curve and the plasma dilution curve are identical in a range from 1 to $70 \mathrm{ng} \mathrm{LH} / \mathrm{ml}$ plasma.

\section{Specificity}

Fig. 1 also shows a dose-response curve for bFSH. It can be calculated that the cross reactivity (C.R.) equals $0.4 \%$ at $50 \%$ of maximal binding - this value is close to the characteristics given by the manufacturer (C.R. $=0.5 \%$, content of LH in FSH preparation $<0.6 \%$ ). Thus, it is stated that the assay fulfills normal demands to specificity.

\section{Sensitivity}

The least detectable amount is below $0.5 \mathrm{ng}$ $\mathrm{LH} / \mathrm{ml}$ plasma when usual assay procedure is followed, and LH-RIA is sufficiently sensitive to measure naturally occurring LH concentrations.

Incubation time plays a great role for the sensitivity. Table 2A depicts a decrease in linearity between samples measured after $20 \mathrm{~h}$ respective to $40-48 \mathrm{~h}$ of incubation for values below $4 \mathrm{ng} \mathrm{LH} / \mathrm{ml}$ plasma as expressed in the difference in coefficients of correlation. When using 40-48 $\mathrm{h}$ of incubation the method provides a good correlation to an established method (Niswender et al. 1969) over all $(\mathrm{y}=0.929 \mathrm{x}+0.125 ; \mathrm{r}=0.996 . \mathrm{t}=$ $2.208>\mathrm{P}(0.05))$ in the range of naturally oc- curring concentrations of $\mathrm{LH}$, and also when different intervals of the dose-response curve are examined, as can be seen from the comparison in Table 2B. This relation is also illustrated in Fig. 2, and no significant differences are seen between results obtained when comparing the two methods.

\section{Conclusion}

A RIA based LH analysis which is based on antibody and antigen from commercial sources has been introduced in our laboratory. It appears that the quality of the analysis is sufficient to fulfill the demands for a precise measurement of bLH in a range which includes both basal level of the hormone and high concentrations of LH during the preovulatory surge.

\section{Acknowledgements}

This work has been supported by grant no. 13-3715 from The Danish Veterinary and Agricultural Research Council.

The author appreciates the work performed with great skill by $\mathrm{K}$. Ejstrup; also the many interesting discussions with $\mathrm{H}$. Callesen and T. Greve upon the scope of the analytical work are acknowledged.

\section{References}

Bernard C, Valet $J P$, Béland $R$, Lambert $R D$ : Prediction of bovine ovulation by a rapid radioimmunoassay for plasma LH. J. Reprod. Fert. 1983, 68, 425-430.

Callesen H, Greve T, Hyttel P: Preovulatory endocrinology and oocyte maturation in superovulated cattle. Theriogenology 1986, 25, 71-86.

Calvo J C, Radicella J P, Charreau F H: Measurement of specific radioactivities in labelled hormones by self-displacement analysis. Biochem. J. 1983, 212, 259-264.

Goff $A$, Greve T, Bousquet D, King W A: Progesteron and LH profiles in heifers used as oocyte donors. Theriogenology 1986, 26, 577-586.

Greenwood F C, Hunter W M, Glover J S: The preparation of ${ }^{131}$ I-labelled human growth hormone of high specific activity. Biochem. J. 1963, 89, 114-123. 
Greve T, Callesen H, Hyttel P: Endocrine Profiles and Egg Quality in the Superovulated Cow. Nord. Med. Vet. 1983, 35, 408-421.

Niswender G D, Reichert Jr. L E, Midgley A R, Nalbandov $A V$ : Radioimmunoassay for bovine and ovine luteinizing hormone. Endocrinology 1969, 84, 1166-1173.

Peterson A J, Fairclough R J, Payne E, Smith J F: Hormonal Changes Around Bovine Luteolysis. Prostaglandins 1975, 10, 675-684.

Schams D, Karg H: Radioimmunologische LH-Bestimmung im Blutserum vom Rind unter besonderer Berücksichtigung des Brunstzyklus (Radioimmunological LH-determination in bovine blood serum with special emphasis on the oestrous cycle). Acta Endocr. 1969, 61, 96-103.

Schams D, Schallenberger E, Hoffmann B, Karg H: The oestrous cycle of the cow: Hormonal parameters and time relationships concerning oestrous, ovulation, and electrical resistance of the vaginal mucus. Acta Endocr. 1977, 86, 180-192.

Stupnicki R, Madej A: Radioimmunoassay of LH in Blood Plasma of Farm Animals. Endokrinologie 1976, 68, 6-13.

Walters $D L$, Schallenberger E: Pulsatile secretion of gonadotrophins, ovarian steroids and ovarian oxytocin during the periovulatory phase of the oestrous cycle in the cow. J. Reprod. Fert. 1984, 71, 503-521.

Walters D L, Schams D, Schallenberger C: Pulsatile secretion of gonadotrophins, ovarian steroids and ovarian oxytocin during the luteal phase of the oestrous cycle in the cow. J. Reprod. Fert. 1984, 71, 479-491.

Yalow $R$, Berson $S A$ : Introduction and General Considerations. In Principles in Competitive Protein-Binding Assays. W. D. Odell \& W. A. Daughaday (eds.). J. B. Lippincott Compagny 1971, 1-24.

\section{Sammendrag}

Radioimmunoassay for bovint luteiniserende hormon baseret pả kommercielt tilgcengelige reagenser. En metode til bestemmelse af bovint luteiniserende hormon (LH) baseret på radio-immunologiske principper og under anvendelse af kommercielt tilgængeligt antistof og antigen er præsenteret. Metoden karakteriseres ved variationskoefficienter: intra assay C.V. fra 1,3 til $10 \%$ og inter assay C.V. fra 4 til $18 \%$. Specificiteen er illustreret ved krydsreaktion af bFSH og findes at være $0,4 \%$. Metoden har vist sig at være i god overensstemmelse med en kendt metode. Endvidere diskuteres inkubationstidens betydning for analysens følsomhed.

(Received July 7, 1987).

Reprints may be requested from: R. Høier, Department of Reproduction, Royal Veterinary and Agricultural University, Bülowsvej 13, DK-1870 Frederiksberg C, Denmark. 